\title{
PENGARUH KONSUMSI EKSTRAK DAUN KATUK TERHADAP KECUKUPAN ASI PADA IBU MENYUSUI DI KLATEN
}

\author{
Endang Suwanti, Kuswati \\ Kementerian Kesehatan Politeknik Kesehatan Surakarta Jurusan Kebidanan
}

\begin{abstract}
Sauropus Androgynus, Breast Milk. Mother breat Milk is good nutrition for baby. Mother breat Milk important for growing baby. To increasing mother breast milk very good consumtion food this like : leaf Katu (Sauropus androgynus), leaf ubi jalar (Ipomoea batatas), leaf kelor (moringa oleifera), fread corn at all, Composition of leaf katuk is proteins, fats, calsium, phosfor, iron, vitamins $A, B$, and $C$. pirolidinon, metil piroglutamat and p-dodesilfenol component minor. Goal reseach to known relationship consumtion leaf katu with breast milk sufficient, at midwife practice Independent (BPM) on Klaten area. Metods: Pre-Posttes with Control Group Design. In the research researcher measure influence intervention at eksperiment group with comparating group control. Research worked at midwife practice Independent at the January as to Juli 2015. Population in the research is all of mother breat feeding at midwife practice Independent (BPM) on Klaten district. Sampling metods is quota sampling with inclusiv criterion normaly newborn and healty. Research at JanuaryJuly 2015. Data analysis performed to describe the variabel that will be studied and performed bivariate analyzes to the relationship of independen and dependent variabel $s$ using the chi square. Results research is $70 \%$ intervention group more produced milk than kontrol group produced milk enough 30\%. Result statistik Analice chi square $p$ value $=0,002$. Conclution there was significant relationship consumtion ekstrac katuk for sufficient breast milk.
\end{abstract}

Keyword : Sauropus Androgynus, Breast Milk

Abstrak: Daun Katu, ASI. ASI (Air susu ibu) adalah makanan terbaik bagi bayi. Kecukupan ASI penting untuk tumbuh kembang bayi. Untuk meningkatkan ASI sagat baik konsumsi makanan seperti daun Katu, daun Ubi jalar, daun kelor, jagung sangrai, dll. Daun katu ini mengandung protein, lemak, kalsium, fosfor, besi, vitamin A, B, dan C. pirolidinon, dan metil piroglutamat serta p-dodesilfenol sebagai komponen minor. Tujuan penelitian adalah untuk mengetahui pengaruh konsumsi ekstrak daun katuk terhadap kecukupan ASI, di BPM wilayah Klaten. Metode yang digunakan adalah metode pre-posttest dengan Kelompok Kontrol (pre-Posttes with Control Group Design). Penelitian ini mengukur pengaruh perlakuan (intervensi) pada kelompok eksperimen dengan cara membandingkan kelompok tersebut dengan kelompok kontrol. Penelitian dilakukan di BPM wilayah Kabupaten Klaten, pada bulan Januari sampai dengan Juli 2015. Populasi: Ibu menyusui di wilayah klaten. Metode sampling quota sampling sebanyak 30 responden dengan kriteria bayi lahir normal dan sehat. Analisis Univariat dilakukan untuk mendiskripsikan variabel yang diteliti dan analisis bivariat menggunakan chi square. Hasil penelitian adalah pada kelompok perlakuan sebelum mengkonsumsi daun katuk 53,3 \% ASI cukup dan setelah konsumsi katuk 70\% ASI 
lebih. Sedangkan pada kelompok kontrol pada observasi sebelum 53\% ASI cukup dan sesudah satu bulan kemudian $37 \%$ ASI cukup , $30 \%$ ASI lebih . Pada analisis statistik uji pengaruh chi square diperoleh hasil nila $\mathrm{p}=0,002$. Kesimpulan: Ada pengaruh yang signifikan konsumsi ekstrak daun katu terhadap kecukupan ASI $(p=0,000)$

Kata Kunci : Daun Katu, ASI

\section{PENDAHULUAN}

ASI (Air Susu Ibu) adalah makanan terbaik bagi bayi. ASI merupakan sumber nutrisi yang terbaik bagi bayi. ASI sangat ideal untuk Tumbang anak. meningkatkan kes, menc peny, dan mengurangi biaya perw kes dan biaya makan (Pasi) (Bartick, 2009). ASI juga melindungi bayi dari berbagai penyakit infeksi seperti diare dan muntah, infeksi telinga dan melindungi bayi dari alergi (Pujiadji, 2005).

Memberikan ASI sesuai kebutuhan bayi berarti keuntungan untuk semua, bayi akan lebih sehat, cerdas dan berkepribadian baik, ibu akan lebih sehat dan menarik. Perusahaan, lingkungan, dan masyarakat pun akan lebih mendapat keuntungan. Menurut Azrul Anwar (2004), ASI sangat penting untuk peningkatkan SDM kita di masa yang akan datang, terutama dari segi kecukupan gizi sejak dini (Utami Roesli, 2008). Dari survei pendahuluan di wilayah desa Jomboran Klaten di dapatkan data 8 dari 10 ibu tidak memberikan ASI secra ekslusif dengan $70 \%$ penyebab kegagalan adalah kurangnya produksi ASI, puting susu lecet dan terjadi pembengkakan payudara.

Sayangnya tidak semua bayi beruntung bisa mendapatkan ASI sesuai kebutuhan k/ASI yang keluar hanya sedikit atau bahkan tidak keluar sama sekali. Secara tradisional upaya untuk memperlancar produksi ASI dengan kinsumsi: daun Katu, daun Ubi jalar, daun kelor, jagung sangrai, dll.

Hormon yang sangat berperan dalam produksi ASI/laktasi adapun hormon oksitosin dan Prolaktin. Keluarnya hormon prolaktin dapat menstimulasi selsel di dalam aleoli untuk memproduksi ASI, dan prolaktin ini juga akan keluar dalam ASI itu sendiri. Kadar prolaktin akan meningkat apabila produksi ASI lebih banyak yaitu pada jam 2 s/d 6 pagi, tetapi kadar prolaktin menjadi rendah saat payudara terasa penuh.

Setelah melahirkan oksitosin juga bermanfaat untuk mengencangkan otototot halus di sekitar alveoli sehingga dapat memeras ASI menuju saluran air susu. Oksitosin berperan penting dalam proses turunnya air susu let-down/milk ejection reflex

Salah satu upaya memperbanyak ASI, adalah meningkatkan kualitas makanan yang berpengaruh secara langsung pada produksi air susu, misalnya sayur-sayuran hijau, daun katuk, daun ubi jalar, daun pepaya dan sebagainya.

\section{Daun katuk}

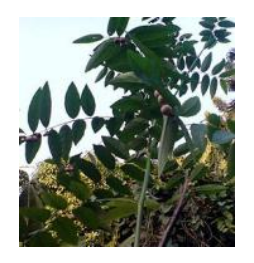

Daun katuk mengandung hampir $7 \%$ protein dan $19 \%$ serat kasar, vitamin $\mathrm{K}$, pro-vitamin A ( beta karotin

Vitmin B dan C. Mineral yang dikandung adalah Kalsium $(2,8 \%)$ zat besi, kalium, fisfor dan magnesium. Perlu diketahui bahwa daun katuk ini juga mengandung 
papaverina, yaitu suatu alkaloid yang juga terdapat pada candu (opium). Konsumsi yang berlebihan dapat menyebabkan efek samping seperti keracunan papaverina. Warna daun katuk yang hijau gelap menunjukkan kadar klorofil yang tinggi. Daun katuk mempunyai sifat yang khas yaitu manis, mendinginkan dan membersihkan darah, khasiat antipiretik dan laktagog.

Uji toksisitas yang dilakukan oleh Lucia, E.W., Dayang., E.M. dan Widayati, S. (1997) dalam Sa'roni, dkk (2004) : uji toksisitas akut dan teratogenik pada mencit menunjukkan bahwa daun katuk tidak toksik dan tidak menibulkan kecacatan pada janin.

\section{METODE PENELITIAN}

Penelitian ini merupakan penelitian dengan jenis Quasi experiment with control. Dalam rancangan ini responden diberi intervensi dengan ekstrak daun katu 2 kali sehari 2 kapsul selama 1 bulan kemudian dilihat kecukupan ASI dengan indikator kecukupan ASI yang meliputi: Frekuensi Bayi Buang Air Kecil (BAK); Warna dan konsistensi Feses; Kondisi bayi saat menyusu (dengan rakus kemudian melemah dan tidur); Payudara lunak setelah disusu; BB Bayi bertambah (14 gram per hari pada usia 3-6 bulan )

\section{HASIL PENELITIAN}

Penelitian dilakukan di BPM yang berada di wilayah Kab Klaten dengan hasil sebagai berikut:

1. Analisis Univariat

Dari analisis univariat didapatkan bahwa responden kelompok intervensi dengan diberikan ekstrak daun katu selama 30 hari dengan dosis 2 kali sehari 1 kapsul mendapatkan hasil bahwa sebagian besar
ASI melebihi kebutuhan bayi (70\%). Sedang pada kelompopk kontrol (tanpa perlakuan) didapatkan data bahwa responden yang produksi ASI nya melebihi kebutuhan bayinya hanya 6,7\% dan masih didapatkan yang kurang memenuhi kebutuhan bayi (20\%). Responden kelompok intervensi selama diberikan ekstrak daun katu dilakukan monitoring setiap 1 minggu 1 kali untuk melihat efek samping atau keluhan ibu yang berkaitan dengan ekstrak daun katu ternyata didapatkan hasil bahwa tidak ada ibu yang mengalami pusing, mual atau muntah layaknya orang keracunan makanan. Hasil tersebut dapat disimpulkan bahwa ibu yang mengkonsumsi ekstrak daun katu membantu memperbanyak produksi ASI dan tidak mengalami keracunan.

2. Analisis Bivariat

Analisis dilakukan dengan uji statitik menggunakan uji Chi-Square, dapat diketahui bahwa ibu-ibu yang mengkonsumsi ekstrak daun katu ASI nya lebih banyak dibandingkan dengan ibu yang tidak mengkonsumsi ekstrak daun katu $(\rho=0.000)$. Hal ini sesuai dengan hasil penelitian Sa'roni, dkk (2004) menunjukan bahwa kelompok ibu melahirkan dan menyusui bayinya yang diberikan ekstrak daun katuk dengan dosis 3 x $300 \mathrm{mg} /$ hari selama 15 hari terus menerus mulai hari ke-2 atau ke-3 setelah melahirkan dapat meningkatkan produksi ASI 50,7\% lebih banyak dibandingkan dengan kelompok ibu yang tidak diberi ekstrak daun katuk.

\section{PEMBAHASAN}

Hasil penelitian Sa'roni, dkk (2004) tersebut mendukung hasil penelitian yang dilaksanakan oleh Djumiati Kustifah, (1991) jurusan FMIPA 
Unair menunjukkan bahwa infus daun katuk per oral dapat meningkatkan kuantitas produksi air susu mencit. Penelitian tersebut didukung oleh hasil penelitian tentang pengaruh pemberian daun Katuk terhadap peningkatan produksi susu kambing yang dilakukan oleh Agik Suprayogi, (1993) dengan hasil bahwa larutan ekstrak daun katuk 20\% yang diberikan secara in vitro dapat meningkatkan produksi susu lebih dari $20 \%$ dan komposisi susu tidak berubah, dan terjadi peningkatan aktifitas metabolisme glukosa sebesar lebih dari 50\%. (IPTEKnet, 2005)

Sesuai dengan hasil penelitian ini bahwa upaya untuk meningkatkan produksi ASI dapat dilakukan dengan megkonsumsi ibu sehari-hari terutama dengan menambah menu sayur daun katuk atau minum kapsul katuk sesuai dosis. Daun katuk sudah dikenal oleh nenek moyang kita sebagai sayur pelancar ASI. Aktifitas fisiologis eksrak daun katu memiliki antioksidan pada tubuh manusia karena dapat menghambat radikal bebas hidroksil. (Narumon Benjapak, dkk (2008) dalam Andari Ana, (2010)

\section{Implikasi terhadap bidang keilmuan}

Implikasi hasil penelitian ini terhadap bidang keilmuan adalah ibu menyusui yang mengkonsumsi ekstrak daun katu efektif dapat meningkatkan kecukupan produksi ASI.

\section{KESIMPULAN DAN SARAN}

Hasil penelitian ini menunjukkan bahwa :

1. Setelah mengkonsumsi ekstrak daun katu ibu yang menyusui mengalami kenaikkan produksi ASI sampai melebihi kebutuhan bayinya (70\%)

2. Ibu-ibu yang tidak mengkonsumsi ekstrak daun katu mengalami kenaikkan produksi ASI sampai melebihi kebutuhan bayinya hanya sebagian kecil saja $(6,7 \%)$

3. Ada pengaruh yang signifikan konsumsi ekstrak daun katu terhadap kecukupan ASI ( $p=0,000)$

Berdasarkan kesimpulan tersebut maka kami menyarankan kepada:

1. Bagi ibu menyusui mau memgkonsumsi daun katu sebagai variasi menu makanan untuk meningkatkan kecukupan ASI

2. Bagi bidan dan pemberi asuhan pada ibu menyusui dapat memberikan KIE tentang daun katu sebagai menu makanan sehari-hari untuk meningkatkan produksi ASI

\section{DAFTAR RUJUKAN}

Andari Ana, 2010, Uji aktifitas ekstrak daun katuk (Sauropus Androgynus L. Meer) sebagai antioksidan pada minyak Kelapa, Skripsi Program Studi Kimia Universitas Islam Negeri Yogyakarta

Anwar, S. 2002, Hak Asasi Bayi dan Pekan ASI Sedunia, Alfabeta, Bandung

Roesli, Utami. 2005, Mengenal ASI Eksklusif, Trubus Agrawijaya, Jakarta

Roesli, Utami. 2008. Inisiasi Menyusu Dini plus ASI Eksklusif, Pustaka Bunda, Jakarta

Sa'roni, dkk, 2004, Effectiveness of the Sauropus Androgynus (L.) Meer Leaf Extract In Increasing Mother's Breast Milk Production, Media Litbangkes Vol XIV No 3 